\title{
Antiserum detection of reactive carbonyl species-modified DNA in human colonocytes
}

\author{
NALINI MISTRY ${ }^{1}$, RUTH J. BEVAN ${ }^{2 *}$, MARCUS S. COOKE ${ }^{3,4}$, \\ MARK D. EVANS ${ }^{3}$, EUGENE P. HALLIGAN $^{5}$, DAMON A. LOWES ${ }^{1}$, \\ KAREN NICHOL ${ }^{1}$ AND JOSEPH LUNEC ${ }^{6}$.
}

\begin{abstract}
${ }^{1}$ Formerly Department of Cancer Studies and Molecular Medicine, University of Leicester, Leicester, UK. ${ }^{2}$ School of Biological Sciences, University of Leicester, Leicester, UK. ${ }^{3}$ Radiation and Oxidative Stress Group, Department of Cancer Studies and Molecular Medicine, University of Leicester, Leicester, UK. ${ }^{4}$ Department of Genetics, University of Leicester, Leicester, UK. ${ }^{5}$ Molecular Toxicology Group, Department of Forensic Science and Drug Monitoring, King's College London, London, UK. ${ }^{6}$ Cranfield Health, Cranfield University, Bedford, UK.
\end{abstract}

\begin{abstract}
Polyunsaturated fats have been linked to occurrences of sporadic colon cancer. One possible cause may be degradation of polyunsaturated fats during cooking, resulting in multiple reactive carbonyl species (RCS) that can damage nuclear DNA and proteins, particularly in rapidly dividing colon crypt cells.
\end{abstract}

Herein, we describe a novel antiserum against RCS-modified DNA, with apparent order of reactivity to DNA modified with 4-hydroxy-trans-2-nonenal > glyoxal $>$ acrolein $>$ crotonaldehyde $>$ malondialdehyde; some reactivity was also 
observed against conjugated Schiff base-type structures. Anti-(RCS-DNA) antiserum was successfully utilised to demonstrate formation of RCS-DNA in a human colon cell model, exposed to RCS insult derived from endogenous and exogenous lipid peroxidation sources. Further utilisation of the antiserum for immunohistochemical analysis confirmed RCS-modified DNA in crypt areas of 'normal' colon tissue. These results fully support a potential role for dietary lipid peroxidation products in the development of sporadic colon cancer.

Key words: Reactive carbonyl species, Colon crypt cells, Antiserum, Colon cancer.

*Corresponding author: Ruth J. Bevan, Tel: +44 (0115) 9826457;

email: ruth.bevan@ntlworld.com 


\section{Introduction}

Reactive carbonyl species (RCS) are predominant products of lipid peroxidation, generated primarily as a result of oxidative degradation of lipid hydroperoxides $[1,2]$. It is also known for RCS to be generated via oxidative sugar degradation [3] as well as being released into the environment from car exhaust fumes and cigarette smoke $[4,5]$. The oxidation of dietary polyunsaturated fatty acids (PUFAs) during food processing and cooking is gaining increasing importance as a source of RCS that may have deleterious effects within the digestive tract $[6,7,8]$. This is especially problematic in Western countries, where diets high in polyunsaturated fatty acids have been associated with an increased risk of sporadic colorectal cancer [9-12].

A well-established hypothesis for the initiation of colonic neoplasia may be as a result of the oxidation of dietary PUFAs during the cooking process [13] and food storage. Redox cycling food chemicals formed during food processing or present as contaminants [6] can, through an autocatalytic process, initiate peroxidation of PUFA and additionally, lipoproteins present as cellular components of the gastrointestinal mucosa. Extensive studies by Wilson et al., [14] and Linsteisen and Wolfram [8] have shown that foodstuffs contain oxidised lipids that are readily absorbed from the diet. PUFAs are readily oxidisable compounds leading to the production of lipid hydroperoxides that decompose to form an extensive number of reactive carbonyl compounds such as malondialdehyde (MDA) and 4-hydroxynonenals (4-HNE) which, in particular, show significant cytotoxicity and mutagenicity following adduction with DNA and protein [15].

Human exposure to RCS is potentially widespread via both endogenous and exogenous sources. Evidence for the generation of RCS has been extensively reviewed, especially in terms of thiobarbituric acid reactive products (TBARS) and 4- 
hydroxy-trans-2-nonenal (HNE)-modified proteins, in diabetes and atherosclerosis $[16,17]$, Alzheimer's disease [18] and colon cancer $[19,20,21]$. The colonic mucosa is composed of crypts lined with epithelial cells, all of which are at varying degrees of proliferation and differentiation. Precursor, or stem cells, lining the base of the crypt are undifferentiated and have a large proliferative capacity, and these cells migrate towards the luminal surface $[22,23,24]$. We propose here, that these undifferentiated, proliferating cells represent a target population for carcinogenesis and that damage to these cells from RCS carries an increased likelihood of initiating carcinogenesis.

DNA adducts formed by RCS are known to possess strong miscoding potential in vitro [25] and of the DNA adducts formed by MDA, pyrimido $(1,2 \alpha)$ purin- $10(3 \mathrm{H})$ one $\left(\mathrm{M}_{1} \mathrm{G}\right)$ is readily detected in many human tissues. Other propano-adducts also originate from $\alpha, \beta$-unsaturated aldehydes or enals such as acrolein (Acr), crotonaldehyde (Cro), glyoxal (Gly) and HNE. Adducts formed by HNE have been detected in healthy human colon tissue [26]. Etheno-DNA adducts are formed from the epoxides of enals and elevated levels of this type reflect the extent of oxidative stress [27]. Antibodies, both poly- and mono-clonal, have been generated against RCS-modified DNA bases. For example, MDA-deoxyguanosine [28], deoxycytidine-glyoxal [29], deoxyadenosine-acrolein [30], 1,N(6)ethenodeoxyadenosine [31] and ethenodeoxyguanosine [32]. These specific RCSDNA antibodies have been successfully used to measure carbonyl stress in human and animal studies following oxidative and peroxidative insult $[33,34]$. However, in an attempt to monitor global carbonyl stress (DNA and protein) we describe the development and characterisation of a novel polyclonal antiserum with apparent reactivity against (a) DNA modified with multiple RCS comprising MDA, HNE, GLY, CROT and ACR, and (b) conjugated Schiff base-type structures formed from 
MDA modification of lysine residues. The application of this anti-(RCS-DNA) antiserum is illustrated by the immunocytochemical demonstration of RCS-modified DNA formation in undifferentiated human colonocytes exposed to products of endogenous and exogenous (dietary) lipid peroxidation. In addition, a further use of the antiserum is demonstrated for the detection of RCS-modified DNA in the immunohistochemical analysis of ex vivo, normal, colon tissue obtained from patients undergoing surgery for colon cancer.

\section{Materials and Methods}

\section{General materials}

Calf thymus DNA was from Calbiochem Novabiochem UK Ltd (Nottingham UK). 96-well Nunc, Immuno Maxisorp ELISA plates were purchased from Life Technologies Ltd (Paisley, Scotland) and dried skimmed milk was from Tesco Stores Ltd, UK. Goat anti-rabbit immunoglobulins IgG, M, A-peroxidase labelled secondary antibody was from DAKO Ltd (High Wycombe, UK). Ethanol was purchased from Fisher Scientific (Loughborough, UK). All other chemicals were obtained from Sigma Chemical Co (Dorset, UK) unless indicated otherwise. Human colonic epithelial cells (CRL-1807) were obtained from the American Tissue Culture Collection Repository (Rockville, MD). Monoclonal antibody $\mathrm{M}_{1} \mathrm{G}$ (anti-MDA-deoxyguanosine) was a gift from Prof LJ Marnett.

\section{Preparation of reactive carbonyl species-modified DNA (RCS-DNA)}

Calf thymus DNA ( $1 \mathrm{mg} / \mathrm{ml}$, final concentration) was incubated in $0.05 \mathrm{M}$ sodium phosphate, $0.003 \%$ Tween 20 buffer, $\mathrm{pH} 7.0$ containing either $10 \mathrm{mM}$ glyoxal (GLY) for one hour at $37{ }^{\circ} \mathrm{C}$ [35]; $0.58 \mathrm{mM}$ 4-hydroxynonenal (HNE prepared in 
tetrahydrofuran, THF), $24 \mu \mathrm{M}$ copper (II) sulphate and $25 \mu 170 \%$ (v/v) t-butyl hydroperoxide in a total volume of $10 \mathrm{ml}$ for two $\mathrm{hr}$ at $37^{\circ} \mathrm{C}$ (conditions adapted from in house methodology); $100 \mathrm{mM}$ malondialdehyde (MDA) for $96 \mathrm{hr}$ at $37{ }^{\circ} \mathrm{C}$ where $100 \mathrm{mM}$ malondialdehyde bis-(dimethyl-acetal) was used to generate MDA(conditions adapted from in house methodology); $1 \mathrm{M}$ acrolein (ACR) for $2 \mathrm{hr}$ at $37^{\circ} \mathrm{C}$ or $0.5 \mathrm{M}$ crotonaldehyde (CROT) for $18 \mathrm{hr}$ at $37^{\circ} \mathrm{C}$ [modified from 36] . DNA was precipitated from aqueous solution using 0.1 volumes, $3 \mathrm{M}$ sodium acetate, pH 5.4 and 2 volumes of ice-cold absolute ethanol. DNA was resuspended in $500 \mu \mathrm{L}$ $\mathrm{H}_{2} \mathrm{O}$, dialysed against two washes of PBS at $4{ }^{\circ} \mathrm{C}$ and stored at $-20^{\circ} \mathrm{C}$.

Modification of DNA was assessed by direct binding ELISA utilising an anti-reactive oxygen species antibody, as described in [35]. Increased binding of antibody over that to native DNA was seen for each aldehyde modified DNA (results not shown).

Preparation of reactive carbonyl species-modified BSA or LDL

BSA $(1 \mathrm{mg} / \mathrm{ml})$ and LDL $(1 \mathrm{mg} / \mathrm{ml})$ were modified as described for calf thymus DNA.

Production of anti-(RCS-DNA) polyclonal antiserum

Immunisation of a New Zealand White rabbit was as described previously for Reactive Oxygen Species -modified DNA (ROS-modified DNA, [32]). The immunogen was prepared using equal volumes of individually modified RCS-DNA.

Immunoglobulin $G$ purification using protein-A.

Prior to characterisation, the anti-(RCS-DNA) antiserum was purified to obtain the IgG fraction using a protein A column. Briefly, 0.125 g Protein A beads (cyanogen 
bromide activated and immobilised on sepharose CL-4B) were allowed to swell in water $(1 \mathrm{~g}$ swells to $\approx 4 \mathrm{ml})$ and passed through a $1 \mathrm{ml}$ column with a bed of glass wool. Antiserum $(1 \mathrm{ml})$ was adjusted to $\mathrm{pH} 8.0$ with $1 \mathrm{M}$ Tris-base and layered onto the protein A column which had been pre-washed using 5 column volumes of 100 $\mathrm{mM}$ Tris, $\mathrm{pH}$ 8.0. Following washing with a further 10 column volumes of $100 \mathrm{mM}$ Tris, $\mathrm{pH}$ 8.0, IgG was eluted with 10-column volumes of $100 \mathrm{mM}$ glycine, $\mathrm{pH}$ 3.0. Each column volume was collected in $1.5 \mathrm{ml}$ aliquots containing $50 \mu \mathrm{L} 1 \mathrm{M}$ Tris, $\mathrm{pH}$ 8.0. IgG containing fractions were identified by UV absorbance at $280 \mathrm{~nm}(1 \mathrm{OD} \approx$ $0.8 \mathrm{mg} / \mathrm{ml}$ ), and subsequently combined. The final concentration of $\mathrm{IgG}$ was 1.78 $\mathrm{mg} / \mathrm{ml}$.

\section{Enzyme-linked immunosorbent assay (ELISA)}

Characterisation of the anti-(RCS-DNA) antiserum was carried out using direct and inhibition ELISA, as previously described [35]. IgG fraction of the antiserum was used at a final dilution of 1:500 $(3.6 \mu \mathrm{g} / \mathrm{ml})$ and secondary peroxidase-labelled antirabbit conjugate at a dilution of 1:2000.

\section{Preparation of heat-oxidised oil mixture}

In order to simulate the effects of exposure to exogenous (dietary) products of lipid peroxidation, a heat-oxidised oil mixture was prepared as follows: $1 \mathrm{ml}$ of Methyllinoleic acid and $1 \mathrm{ml}$ of Methyl-linolenic acid were mixed in an open top heat resistant tube and heated to $180{ }^{\circ} \mathrm{C}$ for $20 \mathrm{~min}$. The oil was then allowed to cool to room temperature for $2 \mathrm{hr}$ and was stored at $-20^{\circ} \mathrm{C}$ under argon until use.

Prior to incubation with cells, a PBS extract of the oil mixture was prepared as follows: $300 \mathrm{ml}$ of heat-oxidised oil was added to $2.7 \mathrm{ml} \mathrm{PBS}$ and vortex mixed for 2 
min, followed by rotational mixing for a further $10 \mathrm{~min}$. The oil/PBS mixture was then centrifuged at $1300 \mathrm{~g}$ for $5 \mathrm{~min}$ and the upper aqueous phase was removed for immediate use.

\section{Human colon epithelial cell culture}

The human normal colon cell line CRL-1807 transformed with heat sensitive SV40 virus (tsSV40) (American Tissue Culture Collection Repository; Rockville, MD) was maintained in $25 \mathrm{~cm}^{3}$ tissue culture flasks in Dulbecco's modified Eagle's medium supplemented with $10 \%(\mathrm{v} / \mathrm{v})$ foetal bovine serum, $50 \mu \mathrm{g} / \mathrm{ml}$ gentamycin at $37^{\circ} \mathrm{C}$ in a humidified atmosphere containing $5 \%(\mathrm{v} / \mathrm{v}) \mathrm{CO}_{2}$.

\section{Exposure of CRL-1807 cells to products of lipid peroxidation}

Two models were used to simulate exposure of colon cells to products of lipid peroxidation;

Model A: Endogenous lipid peroxidation was simulated by treatment of CRL-1807 cells with the lipid peroxidation initiator AAPH (2,2'-azo-bis-(2-aminopropane)dihydrochloride) as follows: CRL-1807 cells were seeded onto 8-well covered glass chamber slides (200 cells/ well) and allowed to attach overnight. Cells were incubated with $600 \mu \mathrm{l}$ of AAPH solution $(1 \mathrm{mM})$ for $24 \mathrm{hr}$ at $37^{\circ} \mathrm{C}$ in a humidified atmosphere of $5 \%(\mathrm{v} / \mathrm{v}) \mathrm{CO}_{2}$.

Model B: Exogenous (dietary) lipid peroxidation was simulated by treatment with a PBS extract of heated oil mixture, as follows: CRL-1807 colon cells were seeded onto 8-well covered glass chamber slides (200 cells/ well) and allowed to attach overnight. Cells were incubated with medium containing either 6 or $15 \mu$ heat 
oxidised oil/ PBS extract for $24 \mathrm{hr}$ at $37{ }^{\circ} \mathrm{C}$ in a humidified atmosphere of $5 \%(\mathrm{v} / \mathrm{v})$ $\mathrm{CO}_{2}$.

Untreated CRL-1807 cells, or cells treated with oil which had not been heat oxidised, were used as controls. Following treatment, the medium was removed and cells were washed twice with cold PBS. Cells were then fixed with $100 \%$ ice-cold ethanol for $5 \mathrm{~min}$, following which excess ethanol was discarded and cells allowed to dry at RT.

\section{Immunocytochemical analysis}

CRL-1807 cells previously exposed to products of lipid peroxidation using either Model A or B, were subsequently analysed for RCS-DNA formation. IgG-fraction of anti-(RCS-DNA) antiserum was added to each chamber (200 $\mu \mathrm{l} /$ chamber;1:500 in PBS) and incubated for $1 \mathrm{hr}$ at $37^{\circ} \mathrm{C}$ in a humidified atmosphere. Following two washes with PBS, a FITC-labelled anti-rabbit IgG antibody (1:100 in PBS; $200 \mu \mathrm{l} /$ chamber) was added and incubated (protected from exposure to light) for a further $1 \mathrm{hr}$ as described above. The slides were then washed twice with PBS before nuclear counterstaining with 4,6-diamidino-2-phenylindole (DAPI, $5 \mu \mathrm{g} / \mathrm{ml} ; 200 \mu \mathrm{l} /$ chamber) for 5 min at RT. Following two washes with PBS, the chambers were removed and the cells mounted using Vectashield fluorescence mounting medium (Vecta Laboratories, Peterborough, UK).

\section{Imaging software}

Images were viewed on an Axioskop fluorescence microscope (magnification x 40) and captured using a Hamamatsu 12-bit digital camera. FITC or DAPI filters were 
placed on a 10-position filter wheel, and controlled using Openlab 3.14 software (Improvision, University of Warwick Science Park, Coventry, UK). Images were originally captured as a 12-bit greyscale image, following which DAPI images were coloured as red (nuclear counterstain) and anti-(RCS-DNA) antiserum binding as green. DAPI and FITC images were subsequently superimposed to assess specific antibody binding to nuclear DNA (yellow/orange).

\section{Immunohistochemical analysis of ex vivo colon tissue}

Samples of 'normal' colon tissue were obtained from ten patients undergoing surgery for colon cancer, nine of whom were subsequently diagnosed with colon cancer.

Tissue samples were initially frozen in liquid nitrogen and stored at $-80^{\circ} \mathrm{C}$. Sections were thawed prior to tissue sectioning ( $8 \mu \mathrm{m}$ thickness) and plated onto microscope slides pre-coated with silane (Sections were prepared by Dept. Histopathology, University Hospitals of Leicester, Leicester Royal Infirmary). Slides were stored at $-80^{\circ} \mathrm{C}$ until required.

Frozen sections were allowed to reach RT for 30 min prior to analysis. Sections were incubated for $30 \mathrm{~min}$ in a blocking solution of PBS, $\mathrm{pH} 7.2$ containing $2 \%(\mathrm{v} / \mathrm{v})$ normal goat serum (NGS) at RT in a covered chamber. Following three washes with PBS, sections were incubated with anti-(RCS-DNA) antiserum (1:500 dilution) or with monoclonal antibody $\mathrm{M}_{1} \mathrm{G}$ (1:500 dilution; reactive against MDAdeoxyguanosine adducts [37] ) as a positive control, for $2 \mathrm{hr}$ at RT in a covered chamber. Control sections were incubated with $2 \%$ (v/v) NGS/PBS. Sections were washed three times with PBS and incubated with a biotinylated goat anti-rabbit immunoglobulins (DAKO E432) or biotinylated goat anti-mouse immunoglobulins (DAKO E433). Control sections (without primary antibody) were treated with 
biotinylated goat anti-mouse immunoglobulins. Sections were washed three times with PBS, followed by incubation with FITC-labelled streptavidin (Vector Labs, SA$5001)$ at 1:100 dilution for $30 \mathrm{~min}$ at RT in a covered chamber. All procedures from this point onwards were carried out in the dark. Sections were rinsed three times with PBS and incubated with DAPI $(1 \mu \mathrm{g} / \mathrm{ml})$ for $5 \mathrm{~min}$ at RT. Sections were then rinsed three times with PBS and mounted using Vectashield fluorescence mounting medium. All sections were subsequently stored in a light-tight container at $4^{\circ} \mathrm{C}$ prior to analysis, as described previously.

\section{Results}

\section{Antigenicity of RCS-modified DNA}

At regular intervals throughout the immunisation schedule, test bleeds were screened by direct ELISA for reactivity against native DNA, the immunogen (comprising a mixture of HNE-, MDA-, GLY -, ACR- and CROT-modified DNA) and DNA modified with individual RCS. Following completion of the immunisation schedule, a bleed-out serum was obtained and purified for the IgG fraction. A working dilution (1:2000) of the anti-(RCS-DNA) antiserum was established by direct ELISA against the immunogen, with minimal reactivity noted against native DNA (Figure 1, inset). Reactivity of the anti-(RCS-DNA) antiserum was also established against DNA modified with individual RCS (Figure 1, main). Reactivity to HNE-modified DNA was comparable to that against the immunogen (mean abs \pm s.d. of $0.741 \pm 0.035$ and $0.789 \pm 0.010$ respectively). Increased reactivity over that to native DNA (mean abs of $0.047 \pm 0.015$ ) was also observed against GLY- and ACR-modified DNA (mean abs of $0.625 \pm 0.017$ and $0.342 \pm 0.012$ respectively). Reactivity of the anti-(RCSDNA) antiserum to CROT- and MDA-modified DNA (mean abs of $0.160 \pm 0.0078$ 
and $0.078 \pm 0.0081$ respectively) was only marginally increased above that against native DNA (mean abs of $0.047 \pm 0.015$ ).

[Insert Figure 1 about here]

The antiserum was further characterised against double- and single-stranded (ds- and ss-DNA) antigens by inhibition ELISA, utilising GLY- DNA as solid phase antigen and anti-(RCS-DNA) antiserum at a dilution of 1:500 (Table 1). Increased reactivity of the anti-(RCS-DNA) antiserum over that to native DNA was observed towards HNE-, GLY- and ACR-modified DNA for both ds- and ss-antigens. For GLY-DNA, the antiserum was considerably more reactive with the ds antigen, in comparison with the ss antigen ( $\mathrm{IC}_{50}$ values of 7 and $178 \mu \mathrm{g} / \mathrm{ml}$ respectively). In contrast, reactivity of the anti-(RCS-DNA) antiserum to ssCROT-DNA and ssHNEDNA $\left(\mathrm{IC}_{50}\right.$ values $>300$ and $175 \mu \mathrm{g} / \mathrm{ml}$ respectively) was generally greater than that to the ds antigens $\left(\mathrm{IC}_{50}\right.$ values of $>400$ and $265 \mu \mathrm{g} / \mathrm{ml}$ for dsCROT-DNA and dsHNE-DNA respectively).

[Insert Table 1 about here]

Cross-reactivity of anti-(RCS-DNA) antiserum to RCS-modified proteins

The immunogen used to generate the anti-(RCS-DNA) antiserum was hydrostatically bound to a protein hapten (BSA) and therefore the antiserum has a potential for crossreactivity to RCS-modified proteins. This was assessed by direct ELISA utilising RCS-modified BSA as antigen. In addition, reactivity to RCS modified low density lipoprotein (LDL) was also investigated as the apolipoprotein component of LDL contains a large proportion of lysine residues which is known to be highly reactive with carbonyl species. Minimal reactivity of the antiserum above that seen to the native antigen was noted for all RCS-modified antigens. However, binding of the anti(RCS-DNA) antiserum to MDA-modified LDL was seen to be significantly raised 
above that of native LDL (mean abs \pm s.d. of $1.1025 \pm 0.014$ and $0.458 \pm 0.032$ respectively; $P<0.0001$; described but not shown).

\section{Utilisation of anti-(RCS-DNA) antiserum for detection of RCS-modified DNA} In vitro Model A: Endogenous lipid peroxidation. CRL-1807 cells were incubated with AAPH (1 mM) to simulate the effects of exposure of colon cells to endogenously derived products of lipid peroxidation. Formation of RCS-modified DNA was subsequently analysed using immunocytochemical techniques, utilising the anti(RCS-DNA) antiserum for detection of RCS-modified DNA. Antibody binding was visualised using an anti-rabbit FITC-labelled secondary antibody conjugate (green fluorescence) with DAPI being used as a nuclear counterstain (red fluorescence). Figure 2a illustrates that increased binding of the antiserum was observed in cells treated with 1mM AAPH (i) over that seen in untreated cells (ii). DAPI staining was consistent in both AAPH treated (iii) and untreated cells (iv).

In vitro Model B: Exogenous lipid peroxidation. CRL-1807 cells were incubated with a PBS extract of heat-oxidised Methyl-linoleic/ linolenic acid mixture to simulate the effects of exposure of colon cells to exogenously-derived products of lipid peroxidation, such as those found in the diet. Formation of RCS-modified DNA was analysed by immunocytochemistry utilising the anti-(RCS-DNA) antiserum, as described for model A. Fig 2b illustrates that CRL-1807 cells incubated with $15 \mu \mathrm{l}$ heat-oxidised Methyl-linoleic/ linolenic acid (ii) showed an increased binding of the antiserum over that seen in CRL-1807 cells incubated with either $6 \mu 1$ heat-oxidised Methyl-linoleic/ linolenic acid (i) or $15 \mu 1$ unoxidised oil as control (iii).

[Insert Figure 2 about here] 


\section{Ex vivo colon tissue}

The anti-(RCS-DNA) antiserum was further utilised for the immunohistochemical analysis of ex vivo samples of 'normal' colon tissue. As shown in Figure 3, a light microscope image (magnification $\mathrm{x} 20$ ) of the colon tissue shows specific apex and crypt structures (i) with nuclear components highlighted using DAPI (ii - red fluorescence). The presence of RCS-modified DNA in the colon tissue was confirmed by an increased binding of the anti-(RCS-DNA) antiserum (iii; green fluorescence) over that seen in the control (iv; no primary antibody). The FITC and DAPI images obtained were subsequently superimposed and showed that RCS-modified DNA was localised within the nuclei of cells associated with colon crypts (v; orange staining). FITC and DAPI images were obtained in the same way for positive control monoclonal antibody $\mathrm{M}_{1} \mathrm{dG}$ and, when superimposed, confirmed localisation of antibody binding within the nuclei of cells associated with colon crypts (vi; orange staining).

[Insert Figure 3 about here]

\section{Discussion}

In this manuscript we describe the characterisation and application of a novel polyclonal antiserum raised against an immuogen comprising a mixture of DNA modified with RCS. The RCS selected for inclusion in this study focused on those known to have significant cytotoxic and mutagenic properties when adducted with DNA or protein [15] and to be present in human tissues [25-27]. The application of specific RCS-DNA antibodies to measure carbonyl stress in human and animal studies has been previously described [33, 34]. In contrast, the approach adopted in this study potentially allows for monitoring of carbonyl stress (DNA and protein) at a 
more global (but not totally inclusive) level, and was successfully demonstrated in human colonic cells exposed to RCS derived from lipid peroxidation.

Using direct binding ELISA against DNA modified with individual RCS as antigen, an apparent order of reactivity of the anti-(RCS-DNA) antiserum was demonstrated as $\mathrm{HNE}>\mathrm{GLY}>\mathrm{ACR}>\mathrm{CROT}>\mathrm{MDA}$. The effect of using the RCSmodified antigens in the ds- or ss- form on antiserum reactivity was assessed by inhibition ELISA. In general, reactivity was seen to be similar to both ds- and ssRCS-modified antigens with the exception of glyoxal-DNA where the antiserum demonstrated considerably greater reactivity to the ds-antigen than to the ss-antigen. MDA-DNA was seen to be less antigenic for the anti-(RCS-DNA) antiserum than native DNA; however the bulky nature of MDA-DNA may have made this antigen unsuitable for use in this type of ELISA format.

It was not within either the aims or the scope of this study to fully characterise the adducts produced during reaction of each RCS with DNA. However, it is possible using published literature for us to postulate the identity of the main adducts formed. The reaction of DNA with HNE was carried out in this study in a comparable way to that described by Douki et al. [38] who identified 1, $N^{2}$-propano-2'-deoxyguanosine as the major adduct formed from the reaction, with $1, N^{6}$-ethenoadenine and $1-N^{2}$ ethenoguanine also being produced, but at significantly lower levels. Similarly, Olsen et al. [39] reported that, under comparable reaction conditions to ours, the major adduct formed from the reaction of Glyoxal and DNA was 2'-deoxyguanosine-glyoxal with 2'-deoxyadenosine-glyoxal adduct also being formed at lower levels. From the study described by Pawlowicz et al, [39] we can also postulate that 2'deoxyadenosine-acrolein adducts are the likely main adducts formed from the reaction of acrolein with DNA, whereas reaction with Crotonaldehyde could have lead to the 
formation of Michael addition products and the Schiff base $N^{2}$-(3-hydroxybut-1ylidene)dG [40]. For the remaining RCS used in our study, MDA, we can surmise from the work reported by Marnett [25] that the most abundant adduct formed by reaction of MDA and DNA is likely to have been pyrimidol[1,2 $\alpha]$ purin-10(3H0-one, $\mathrm{M}_{1} \mathrm{G}$, with $N^{6}$-(3-oxo-propenyl) deoxyadenosine, $\mathrm{M}_{1} \mathrm{~A}$ being formed at lower levels. $N^{4}$-(3-oxopropenyl)deoxycytidine, $\mathrm{M}_{1} \mathrm{C}$, may also have been present but in trace amounts.

The potential cross-reactivity of the anti-(RCS-DNA) antiserum to RCSmodified proteins was assessed using RCS-modified BSA and LDL. Although BSA was used as a hapten during immunization and a degree of cross-reactivity could therefore reasonably be expected, negligible recognition of RCS-modified BSA over that to native BSA was observed. Recognition of RCS-modified LDL by the antiserum was also negligible, with the exception of MDA-LDL where reactivity was seen to be significantly higher $(p<0.0001)$ than to native LDL. These results suggest recognition of conjugated Schiff base-type structures by the anti-(RCS-DNA) antiserum, formed during MDA-modification of lysine residues on the apolipoprotein B component of LDL [41].

Following characterisation, the utilisation of the anti-(RCS-DNA) antiserum for both immunocytochemical and immunohistochemical analysis was successfully demonstrated. A human epithelial colon cell-model, comprising CRL-1807 cells was exposed to an RCS insult derived from endogenous (using AAPH) and exogenous (using an extract of heat-oxidised Methyl-linoleic/linolenic acids) lipid peroxidation sources. RCS-modified DNA formation was demonstrated for both sources of RCS with increased binding of the anti-(RCS-DNA) antiserum localised to the cell nucleus. A degree of antiserum binding within the cell cytoplasm was also noted (data not 
shown) with the exogenous lipid peroxidation model, suggesting reactivity of the antiserum against RCS-modified lysine or extrusion of damaged DNA that may be associated with DNA repair processes. However, it has been reported using Microarray analysis, that undifferentiated CRL-1807 cells are only able to initiate DNA repair processes in response to DNA damage resulting from exposure to RCS from endogenous and not exogenous lipid peroxidation [42]. Therefore, it would seem more likely that antiserum binding within the cell cytoplasm was due to reactivity with RCS-modified lysine residues.

The study reported here also demonstrated the successful utilisation of the anti-(RCS-DNA) antiserum in the immunohistochemical analysis of 'normal' colon tissue samples obtained from ten patients undergoing surgery for colon cancer. Subsequent to the immunohistochemical analysis, nine of the ten patients from whom samples were taken were positively diagnosed with colon cancer. RCS-modified DNA was detected in the majority of samples using both the anti-(RCS-DNA) antiserum and anti-(MDA-deoxyguanosine) monoclonal antibody $\left(\mathrm{M}_{1} \mathrm{G}\right)$ and was found to predominate in colon crypts. These results strongly indicate that the undifferentiated stem cells located at the base of colon crypts, sustain greater damage from lipid peroxidation products (whether from an endogenous or exogenous source) than the differentiated cells at the apex. Together with supporting evidence showing that CRL-1807 cells exposed to exogenous lipid peroxidation products are unable to initiate a DNA repair response [42] the results reported here strongly support a role for oxidised PUFA intake as a contributing factor in development of sporadic colorectal cancer. 


\section{Acknowledgements}

We gratefully acknowledge financial support from the Food Standards Agency (Project No. T01016).

\section{References}

[1] Roberts MJ, Wondrak GT, Laurean DC, Jacobson MK, Jacobson EL. DNA damage by carbonyl stress in human skin cells. Mutat. Res. 2003; 522:45-56.

[2] Marnett LJ. Oxy radicals, lipid peroxidation and DNA damage. Toxicology 2002; $181-182: 219-222$.

[3] Murata-Kamiya N, Kamiya H, Iwamoto N, Kasai H. Formation of a mutagen, glyoxal, from DNA treated with oxygen free radicals. Carcinogenesis 1995; 16:22512253.

[4] Jing L, Steinberg SM, Johnson BJ. Aldehyde and monocyclic aromatic hydrocarbon mixing ratios at an urban site in Las Vegas, Nevada. J. Air Waste Manag. Assoc 2001; 51:1359-1366.

[5] Chung FL, Hecht SS. Formation of the cyclic 1,N2-glyoxal-deoxyguanosine adduct upon reaction of N-nitroso-2-hydroxymorpholine with deoxyguanosine. Carcinogenesis 1985; 6:1671-1673. 
[6] Ide ML, Kaneco M, Curutti P. Benzo[a]pyrene and ascorbate CuSo4 induced DNA damage in human cells by indirect action. In: McBrain DCH, Slater TF, editors. Protective Agents in Cancer. New York:Academic press; 1983. p293-314.

[7] Wilson R, Lyall L, Smyth CE, Fernie RA, Riemersma R. Dietary hydroxy fatty acids are absorbed in humans: implications for the measurement of 'oxidative stress' in vivo. Free Radic. Biol. Med. 2002; 32:162-168.

[8] Linsteisen J, Wolfram G. Absorption of cholesterol oxidation products from ordinary foodstuff in humans. Ann. Nutr. Metab. 1998; 4:221-230.

[9] World Cancer Research Fund/American Institute for Cancer Research. Food, nutrition and the Prevention of Cancer: a global perspective. In: Cancers, nutrition and food. BANTA Book Group; 2005.p216-251.

[10] Potter J.D, Slattery ML, Bostick RM, Gapstur SM. Colon cancer: a review of the epidemiology. Epidemiol. Rev. 1993; 15: 499-545.

[11] Howe GR, Benito E, Castelleto R, Cornee J, Esteve J, Gallagher, RP. Dietary intake of fiber and decreased risk of cancers of the colon and rectum: evidence from the combined analysis of 13 case-control studies. J. Natl. Cancer Inst. 1992; 84: $1887-$ 1896.

[12] Howe GR, Aronson KJ, Benito E, Castelleto R, Cornee J, Esteve J, Gallagher RP. The relationship between dietary fat intake and risk of colon cancer: evidence 
from the combined analysis of 13 case-control studies. Cancer Causes Control 1997; $8: 215-228$

[13] Claxson AW, Hawkes GE, Richardson DP, Naughton DP, Haywood RM, Chander CL, Atherton M, Lynch EJ, Grootveld MC. Generation of lipid peroxidation products in culinary oils and fats during episodes of thermal stressing: a high field $1 \mathrm{H}$ NMR study. FEBS Lett. 1994; 355:81-90.

[14] Wilson R, Lyall L, Smyth CE, Fernie RA, Riemersma R. Dietary hydroxyl fatty acids are absorbed in humans: implications for the measurement of 'oxidative stress' in vivo. Free Radic. Biol. Med. 2002; 32: 162-168.

[15] Esterbauer H, Schaur RJ, Zollner H. Chemistry and biochemistry of 4hydroxynonenal, malondialdehyde and aldehydes. Free Radic. Biol. Med. 1991; 11: 81-128.

[16] Turk HM, Sevinc A, Camci C, Cigli A, Buyukberber S, Savli H, Bayraktar N. Plasma lipid peroxidation products and antioxidant enzyme activities in patients with type 2 diabetes mellitus. Acta. Diabetol. 2002; 39:117-122.

[17] Hoff HF, O'Neil J, Chisolm GM $3^{\text {rd }}$, Cole TB, Quehenberger O, Esterbauer H, Jurgens G. Modification of low density lipoprotein with 4-hydroxynonenal induces uptake by macrophages. Arteriosclerosis 1989; 9:538-549. 
[18] Girones X, Guimera A, Cruz-Sanchez C-Z, Ortega A, Sasaki N, Marita Z, Lafuente JV, Kalaria R, Cruz-Sanchez FF. $N^{\varepsilon}$-Carboxymethyllysine in brain aging, diabetes mellitus and alzheimer's disease. Free Radic. Biol. Med. 2004; 36: 12411247.

[19] O'Shea M, Stanton C, Devery R. Antioxidant enzyme defence responses of human MCF-7 and SW480 cancer cells to conjugated linoleic acid. Anticancer Res. 1999; 19:1953-1959.

[20] Gederaas OA, Lagerberg JW, Brekke O, Berg K, Dubbelman TM. 5aminolevulinic acid induced lipid peroxidation after light exposure on human colon carcinoma cells and effects of alpha-tocopherol treatment. Cancer Lett. 2000; 159:2332.

[21] Schaeferhenrich A, Beyer-Sehlmeyer G, Festag G, Kuechler A, Haag N, Weise A, Liehr T, Claussen U, Marian B, Sendt W, Scheele J, Pool-Zobel BL. Human adenoma cells are highly susceptible to the genotoxic action of 4-hydroxy-2-nonenal. Mutat. Res. 2003; 526:19-32.

[22] Potten CS, Morris RJ. Epithelial stem-cells in vivo. J. Cell Sci. 1988; Suppl. 10: $45-62$.

[23] Hall PA, Watt FM. Stem cells: the generation and maintenance of cellular diversity. Development 1989;106: 619-633. 
[24] Hong MY, Chang,WC, Chapkin RS, Lupton JR. Relationship among colonocyte proliferation, differentiation and apoptosis as a function of diet and carcinogen. Nutr. Cancer 1997; 28:20-29.

[25] Marnett LJ. Lipid peroxidation-DNA damage by malondialdehyde. Mut. Res. $1999 ; 424: 83-95$.

[26] Wacker M, Schuler D, Wanek P, Eder E. Development of a ${ }^{32}$ P-postlabeling method for the detection of 1, N(2)-propanodeoxyguanosine adducts of trans-4hydroxy-2-nonenal in vivo. Chem. Res. Toxicol. 2000; 13:1165-1173.

[27] Bartsch H, Nair J. New DNA-based biomarkers for oxidative stress and cancer chemoprevention studies. Eur. J. Cancer 2000; 36:1229-1234.

[28] Sevilla CL, Mahle NH, Eliezer, N, Uzieblo A, O'Hara SM, Nokubo M, Miller R, Rouzer CA, Marnett LJ. Development of monoclonal antibodies to the malondialdehyde- deoxyguanosine adduct, pyrimidopurinone. Chem. Res. Toxicol. 1997; 10:172-180.

[29] Mistry N, Podmore I, Cooke M, Butler P, Griffiths H, Herbert K, Lunec J. Novel monoclonal antibody recognition of oxidative DNA damage adduct, deoxycytidineglyoxal. Lab. Invest. 2003; 83:241-250. 
[30] Kawai Y, Furuhata A, Toyokuni S, Aratani Y, Uchida K. Formation of acroleinderived 2'-deoxyadenosine adduct in an iron-induced carcinogenesis model. J Biol. Chem. 2003; 278:50346-50354.

[31] Frank A, Seitz HK, Bartsch H, Frank N, Nair J. Immunohistochemical detection of 1,N6-ethenodeoxadenosine in nuclei of human liver affected by diseases predisposing to hepato-carcinogenesis. Carcinogenesis 2004; 25: 1027-1031.

[32] Foiles PG, Miglietta LM, Nishikawa A, Kusmierek JT, Singer B, Chung,FL. Development of monoclonal antibodies specific for 1,N2-ethenodeoxyguanosine and N2,3-ethenodeoxyguanosine and their use for quantitation of adducts in G12 cells exposed to chloroacetaldehyde. Carcinogenesis 1993; 14:113-116.

[33] Cooke MS, Mistry N, Ahmad J, Waller H, Langford L, Bevan RJ, Evans MD, Jones GD, Herbert KE, Griffiths HR, Lunec J. Deoxycytidine glyoxal: lesion induction and evidence of repair following vitamin $\mathrm{C}$ supplementation in vivo. Free Radic. Biol. Med. 2003; 34:218-225.

[34] Zhang Y, Chen SY, Hsu T, Santella RM. Immunohistochemical detection of malondialdehyde-DNA adducts in human oral mucosa cells. Carcinogenesis 2002; 23:207-211.

[35] Mistry N, Evans MD, Griffiths HR, Kasai H, Herbert KE, Lunec, J. Immunochemical detection of glyoxal DNA damage. Free Radic. Biol. Med. 1999; 26:1267-1273. 
[36] Chung F-L, Young R, Hecht S. Formation of cyclic 1, $\mathrm{N}^{2}-$ propanodeoxyguanosine adducts in DNA upon reaction with acrolein or crotonaldehyde. Cancer Res. 1984; 44:990-995.

[37] Marnett LJ. Chemistry and biology of DNA damage by malondialdehyde. IARC Sci. Publ. 1999; 150:17-27.

[38] Douki T, Odin F, Caillat S, Favier A, Cadet J. Predominance of the 1, $N^{2}$-propano 2'-deoxyguanosine adduct among 4-hydroxy -2-nonenal-induced DNA lesions. Free Radic. Biol. Med. 2004; 37:62-70.

[39] Pawlowicz A, Munter T, Zhao Y, Kronberg L. Formation of acrolein adducts with 2'-deoxyadenosine in calf thymus DNA. Chem. Res. Toxicol. 2006; 19:571-576.

[40] Hecht S, McIntee E, Wang M. New DNA adducts of crotonaldehyde and acetaldehyde. Toxicol. 2001; 166: 31-36.

[41] Gillotte KL, Horkko S, Witztum JL, Steinberg, D. Oxidized phospholipids, linked to apolipoprotein B of oxidized LDL, are ligands for macrophage scavenger receptors. J. Lipid Res. 2000; 41:824-833.

[42] Halligan EP, Lowes D, Mistry N, Dove R, Cooke M, Evans M, Lunec, J. A comparison of the gene expression profiles of CRL-1807 colonocytes exposed to 
RCS-modified DNA in colonocytes

endogenous AAPH-generated peroxides and exogenous peroxides from heated oil. Redox Report 2007;12: 1-5. 


\section{$\mathrm{IC}_{50}(\mu \mathrm{g} / \mathrm{ml})$}

Competitor

\begin{tabular}{ccc}
\hline HNE-DNA & 265 & 175 \\
Gly-DNA & 7 & 178 \\
Acr-DNA & 157 & 199 \\
Crot-DNA & $>400$ & $>300$ \\
MDA-DNA & $>635$ & $>970$ \\
Native-DNA & $>525$ & 369
\end{tabular}

Table 1. Reactivity of anti-(RCS-DNA) antiserum. Inhibition of antiserum binding by double- and single-stranded DNA modified with reactive carbonyl species. $\mathrm{IC}_{50}$ values (concentration of antigen giving 50\% inhibition of antibody binding; $\mu \mathrm{g} / \mathrm{ml}$ ) were determined using inhibition ELISA with glyoxal-modified DNA as solid phase antigen. All values represent the mean of duplicate determinations. HNE = 4-hydroxynonenal; Gly = glyoxal; Acr = acrolein; $\mathrm{Crot}=$ crotonaldehyde; MDA = malondialdehyde 


\section{RCS-modified DNA in colonocytes}

Figure 1. Reactivity of anti-(RCS-DNA) antiserum. Direct binding ELISA was used to assess reactivity of the antiserum against DNA modified with reactive carbonyl species $(\mathrm{RCS})$; native $=$ native DNA; immunogen = mixture of DNA modified with individual RCS; HNE = DNA modified with 4hydroxynonenal; Glyoxal = DNA modified with glyoxal; MDA = DNA modified with malondialdehyde; Crot $=$ DNA modified with crotonaldehyde; Acr $=$ DNA modified with acrolein . Inset shows reactivity of anti-(RCS-DNA) antiserum against immunogen and native DNA, as determined by direct binding ELISA. All values represent the mean absorbance at $492 \mathrm{~nm}( \pm$ s.d) of triplicate determinations for each RCS-modified or native DNA.

Figure 2a. Immunocytochemical analysis of anti-(RCS-DNA) modified antiserum binding to human normal epithelial (CRL-1807) cells exposed to endogenous lipid peroxidation. Antibody binding in cells exposed to (i) $1 \mathrm{mM}$ AAPH and (ii) untreated controls was visualised using anti-rabbit FITClabelled secondary antibodies (green fluorescence). DAPI (red fluorescence) was also used as a nuclear counterstain on AAPH treated (iii) and untreated control cells (iv). Figure 2b.Immunocytochemical analysis of anti-(RCS-DNA) antiserum binding to undifferentiated human normal epithelial (CRL1807) cells exposed to exogenous lipid peroxidation (PBS extract of heat-oxidised Methyl-linoleic/ linolenic acid). Antibody binding in cells exposed to (i) $6 \mu \mathrm{l}$ or (ii) $15 \mu \mathrm{l}$ of heat-oxidised oil or (iii) 15 $\mu 1$ of unoxidised oil as control was visualised using anti-rabbit FITC-labelled secondary antibodies. FITC images (green staining) are shown superimposed on images from DAPI nuclear counterstaining (red staining) and positive binding of anti-(RCS-DNA) antiserum can be identified as areas of yellow staining.

Figure 3. Immunohistochemical analysis of anti-(RCS-DNA) antiserum and anti-(MDAdeoxyguanosine) monoclonal antibody $\left(\mathrm{M}_{1} \mathrm{dG}\right)$ binding to ex vivo colon tissue section. (i) light microscope image (x 20 magnification) of colon tissue showing crypt and apex structures; (ii) DAPI nuclear counterstaining of colon tissue; (iii) anti-(RCS-DNA) antiserum binding to colon tissue visualised with anti-rabbit FITC-labelled secondary antibodies (green staining); (iv) no primary antibody control visualised with anti-rabbit FITC-labelled secondary antibodies (green staining); (v) superimposed FITC and DAPI image showing localisation of anti-(RCS-DNA) antiserum binding to 
RCS-modified DNA in colonocytes

colon crypts (orange staining); (vi) superimposed FITC and DAPI image showing localisation of monoclonal antibody $\mathrm{M}_{1} \mathrm{dG}$ binding to colon crypts (orange staining). 